\title{
SOSIALISASI RISIKO DAN LATIHAN \\ PENCEGAHAN CARPAL TUNNEL SYNDROME (CTS) \\ TERKAIT PENGGUNAAN GAWAI PADA MAHASISWA ASRAMA PUTRA STIKES SUAKA INSAN BANJARMASIN
}

\author{
Bernadus Sadu $^{*}$, Ninuk Kusumawati ${ }^{2}$ \\ ${ }^{1,2}$ Sarjana Fisioterapi, Sekolah Tinggi Ilmu Kesehatan Suaka Insan Banjarmasin \\ *Email : bernadussadu@gmail.com
}

\begin{abstract}
ABSTRAK
Penggunaan gawai/gadget sangat membantu seseorang dalam menyelesaikan pekerjaan atau tugas. Namun penggunaan perangkat teknologi seperti gawai/gadget secara berlebihan (dengan posisi tangan yang salah) dapat menyebabkan munculnya masalah kesehatan seperti Carpal Tunnel Syndrome (CTS). CTS merupakan sekumpulan gejala yang muncul diarea pergelangan tangan dan jari-jari tangan (jari-I sampai dengan sebagian jari-IV) disebabkan oleh terjadinya penekanan/kompresi pada saraf medianus di pergelangan tangan (carpal tunnel). Sosialisasi terkait CTS perlu dilakukan untuk meningkatkan pengetahuan mahasiswa asrama putra STIKes Suaka Insan tentang risiko dan latihan sederhana pencegahan CTS. Sosialisasi dilakukan dengan metode ceramah, diskusi dan demonstrasi latihan pencegahan CTS diikuti seluruh peserta. Untuk melihat tingkat pengetahuan peserta terkait risiko dan latihan pencegahan CTS maka dilakukan pengukuran tingkat pengetahuan peserta dengan melakukan pre-test dan post-tes menggunakan angket. Hasil pre-test $90.9 \%$ peserta menjawab tidak tahu, sedangkan setelah sosialisasi/post-test didapatkan $77,3 \%$ peserta menjawab tahu dan sisanya pada kategri sangat tahu dan sedikit tahu. Sosialisasi cukup berhasil ditandai dengan antusiasme peserta dengan memberikan banyak pertanyaan saat sesi diskusi dan partisipasi peserta memperagakan latihan pencegahan CTS.
\end{abstract}

Kata Kunci : Carpal Tunnel Syndrome, Gawai, Risiko, Latihan, Sosialisasi

\section{A. PENDAHULUAN}

Kemajuan dalam bidang teknologi merupakan sesuatu yang tidak bisa dihindari dalam kehidupan ini, karena kemajuan teknologi akan berjalan sesuai dengan kemajuan ilmu pengetahuan. Setiap inovasi teknologi yang diciptakan dapat memberikan manfaat positif bagi kehidupan manusia (Pramandani \& Wirawan, 2021). Tahun 2018, Massachusetts Institute of Technology menyatakan bahwa 95,7\% dari populasi di Jepang memiliki perangkat seluler, dengan 79,2\% memiliki smartphone.
Data juga menunjukkan peningkatan yang stabil dalam waktu yang dihabiskan untuk mengkses Internet; pada tahun 2019, 89,8\% orang berusia di atas 20 tahun, dari 40.000 rumah tangga, menghabiskan 112 menit setiap hari menggunakan Internet (Saito \& Saito, 2021). Indonesia berada pada posisi kelima sebagai negara pengguna terbesar internet di seluruh dunia dengan 143,26 juta pengguna di tahun 2019. Pada tahun 2020, Indonesia memiliki 175,4 juta pengguna internet. Jumlah pengguna internet di Indonesia adalah lebih dari 
setengah jumlah populasi Indonesia yaitu 272,1 jiwa (Batara et al., 2021).

Gawai berkembang untuk memudahkan manusia dalam kehidupan sehari-hari layaknya kebutuhan primer bagi kehidupan manusia. Di balik segala kemudahan yang didapatkan, terdapat dampak positif dari penggunaan gawai yaitu menambah ilmu pengetahuan, mempermudah komunikasi dan memperluas jaringan pertemanan. Selain dampak positif, terdapat dampak negatif dari penggunaan gawai yaitu memberikan efek kurang baik pada kesehatan tubuh, salah satunya adalah keluhan pada muskuloskeletal (Batara et al., 2021).

Saat mengoperasikan smartphone atau gawai dalam waktu lama, pengguna berisiko mengalami cedera akibat gerakan berulang. Beberapa penelitian telah melaporkan tingginya tingkat gangguan muskuloskeletal pada individu berusia muda, yang disebabkan oleh penggunaan smartphone/gadget. Alhazmi et al., 2018 menemukan bahwa dari 650 mahasiswa $(27,2 \%)$ menggunakan smartphone selama lebih dari 8 jam setiap hari (rata-rata dan standar deviasi 6,65 4,3 jam). Woo et al., 2016 menganalisis penggunaan smartphone atau komputer tablet, ditemukan bahwa aktivitas ini memberi tekanan berlebihan pada saraf medianus, jika gerakan berulang ini berlangsung lama. Selain itu, rata-rata, peserta menggunakan perangkat elektronik selama lebih dari 3 jam setiap hari dan melaporkan keluhan muskuloskeletal. Gangguan muskuloskeletal terjadi ketika bagian tubuh dipaksa untuk bekerja lebih keras secara berlebihan. Tingkat keparahan dari dampak gangguan atau cedera yang terjadi berbeda-beda tergantung dari penyebabnya. Menggenggam perangkat gawai yang terlalu lama dan berulang-ulang bisa menjadi faktor risiko yang dapat menyebabkan keluhan muskuloskeletal (Batara et al., 2021). Baabdullah et al., 2020 menemukan adanya berkorelasi positif dari keluhan pada pergelangan tangan dengan tingkat penggunaan smartphone, dengan $66,4 \%$ peserta merupakan pecandu smartphone/gawai. Salah satu gangguan muskuloskeletal yang paling sering terjadi akibat penggunaan samartphone/gawai secara berlebihan adalah CTS (Pramandani \& Wirawan, 2021).

Carpal tunnel syndrome (CTS) adalah kondisi medis yang disebabkan oleh kompresi saraf median di terowongan karpal karena proses degenerasi atau penggunaan tangan yang berlebihan (Koyama et al., 2021). Carpal Tunnel Syndrome (CTS) atau sindroma terowongan karpal (STK) merupakan 
salah satu gangguan pada lengan tangan akibat penyempitan terowongan karpal, baik akibat edema fasia maupun akibat kelainan pada tulang-tulang kecil tangan sehingga terjadi penekanan terhadap nervus medianus (Pramandani \& Wirawan, 2021). Carpal tunnel syndrome (CTS) adalah jenis neuropati yang paling umum dengan prevalensi diperkirakan antara $0,1-0,5 \%$ dari penduduk dunia. Kondisi ini karena terjadi penekanan pada saraf medianus oleh tendon fleksor wrist di dalam retinaculum/carpal tunnel, menyebabkan kelemahan, parestesia dan nyeri pada pergelangan tangan dan tangan, dan dengan demikian menurunkan kualitas hidup (Polat et al., 2020).

Faktor risiko yang berpengaruh terjadinya keluhan muskuloskeletal yaitu melakukan gerakan repetitif dalam jangka waktu lama. Penggunaan gawai secara aktif dengan posisi tubuh yang tidak baik memberikan efek pada otot sepanjang leher, bahu, lengan, pergelangan tangan dan jari tangan. Hal tersebut dapat memperbesar risiko biomekanikal dibandingkan dengan penggunaan telepon pasif. Berat beban dari perangkat gawai yang dipegang dapat memperbesar keluhan pada muskuloskeletal terutama pada bahu dan lengan. Beberapa faktor diketahui menjadi risiko terhadap terjadinya CTS, seperti gerakan berulang dengan kekuatan, tekanan pada otot, getaran, suhu, postur kerja yang tidak ergonomik dan lain - lain. Masa kerja juga merupakan salah satu faktor individu terkena CTS, semakin lama masa kerja maka akan semakin besar risiko terkena CTS. Masa timbulnya CTS berkisar sampai 5-10 tahun. CTS paling banyak terjadi pada usia 29-62 tahun, risiko meningkat pada usia 40-60 tahun (Batara et al., 2021). Hasil observasi pada mahasiswa asrama putra STIKes Suaka Insan Banjarmasin, dimana mahasiswa sering menghabiskan yang cukup lama setiap hari untuk menggunakan perangkat elektrotik gawai, hal ini tentunya menjadikan mahasiswa sangat berisiko mengalami CTS. Berdasarkan hasil temuan dari obervasi awal tersebut, maka perlu dilakukan sosialisasi untuk mengenalkan kepada mahasiswa asrama putra STIKes Suaka Insan Banjarmasin terkait penyebab/risiko dan latihan sederhana yang dapat dilakukan untuk pencegahan CTS.

\section{B. METODE}

Kegiatan sosialisasi ini dilakukan dengan menggunakan metode ceramah, tanya jawab dan demonstrasi. Adapun tahapan sosialisasi sebagai berikut:

1. Tahap Persiapan: 
Persiapan diawali dengan

melakukan observasi pada

mahasiswa asrama putra STIKes

Suaka Insan Banjarmasin terkait

kebiasaan mahasiswa dalam

penggunaan perangkat teknologi

yaitu penggunaan gawai.

Selanjutnya melakukan koordinasi dengan pihak asrama putra STIKes

Suaka Insan Banjarmasin, untuk kesepakan waktu pelaksanaan sosialisasi.

2. Tahap Pelaksanaan Kegiatan

Sosialisasi diawali dengan melakukan pengukuran tingkat pengetahuan peserta (pre-test) menggunakan angket, kemudian dilakukan pemaparan materi (ceramah) terkait risiko CTS dan demonstrasi latihan pencegahan CTS di ikuti oleh semua peserta, di ikuti sesi diskusi dan tanya jawab. Kegiatan diakhiri dengan kembali mengukur tingkat pengatahuan peserta (post-test) terkait materi yang telah disampaikan menggunakan angket yang sama.

\section{Latihan Mencegah Nyeri Pergelangan Tangan (CTS)}

(Dosis latihan: 1-2 x/hari, minimal 2-3 $\mathrm{x} /$ minggu )
1) Membuka dan Menggenggam Telapak Tangan
a. Posisi awal duduk tegak
b. Tangan yang akan di latih lurus kedepan, dengan telapak tangan terbuka (extensi wrist)
c. Lakukan gerakan menggenggam dan membuka telapak tangan secara perlahan
d. Lakukan pengulangan sebanyak 5 kali
e. Lakukan bergantian pada kedua tangan (lihat gambar 1).

Gambar 1. Latihan Membuka dan Menggenggam Tangan
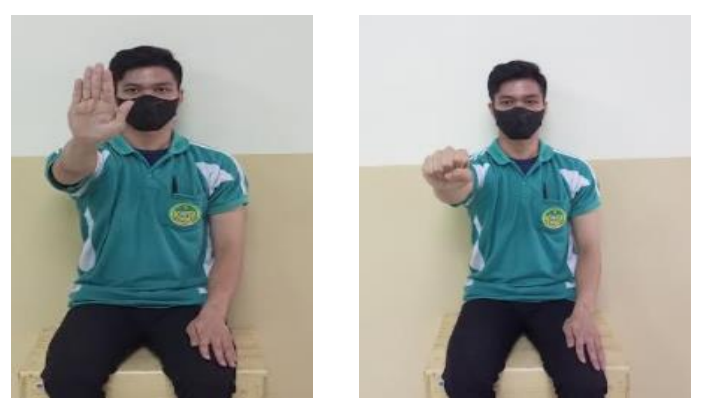

2) Menyentuhkan Ujung Jari-Jari Tangan

a. Posisi awal seperti pada latihan pertama

b. Gerakan ujung jari lain secara bergantian untuk menyentuh ibu jari

c. Lakukan pengulangan sebanyak 3 kali

d. Lakukan bergantian pada kedua tangan (Lihat Gambar 2). 
Gambar 2. Latihan menyentuh ujung jarijari tangan

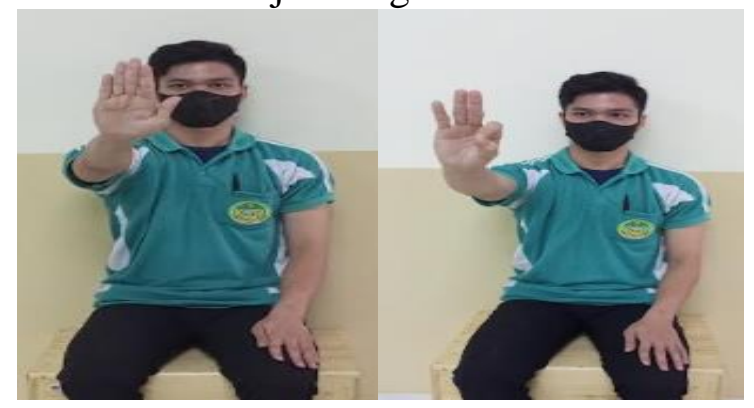

3) Menggenggam Pergelangan Tangan

a. Posisi awal salah satu tangan lurus kedepan, dengan telapak tangan tergenggam dan menghadap keatas

b. Tangan yang lain menggenggam area pergelangan tangan

c. Tahan genggaman sekitar 2 detik

d. Lakukan bergantian pada kedua tangan (Lihat Gambar 3).

Gambar 3. Latihan Menggenggam Tangan

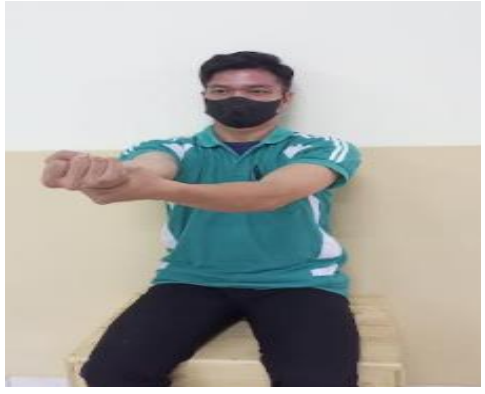

4) Peregangan Otot Tangan Dengan Posisi Seperti Berdoa

a. Posisi awal kedua tangan didepan dada dengan telapak tangan saling bersentuhan (seperti sikap berdoa)

b. Turunkan posisi telapak tangan yang bersentuhan perlahan kearah bawah sambil tetap menjaga seluruh permukaan tangan tetap persentuhan

c. Tahan posisi tersebut selama 30 detik (Lihat Gambar 4)

Gambar 4. Latihan Peregangan otot tangan

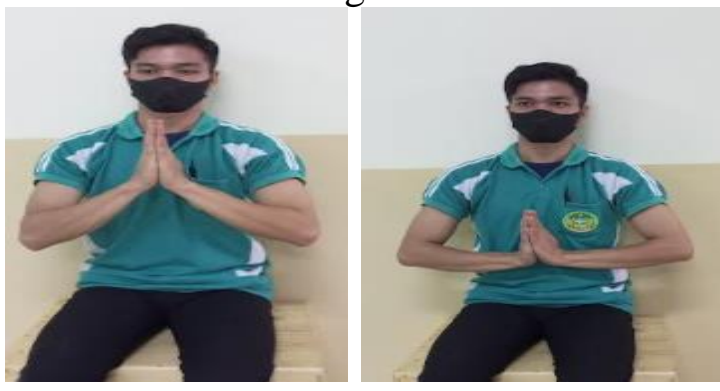

5) Peregangan Otot Flexor

a. Posisi awal duduk tegak tangan lurus kedepan dengan pergelangan tangan menekuk keatas (extensi wrist)

b. Tangan yang lain menggenggam jari ke- 2 sampai dengan jari ke-5

c. Tarik telapak tangan yang digenggam kearah belakang (extensi wrist) secara perlahan

d. Tahan posisi tersebut selama 30 detik

e. Lakukan bergantian pada kedua tangan (Lihat Gambar 5). 
Gambar 5. Latihan Peregangan Otot Flexor

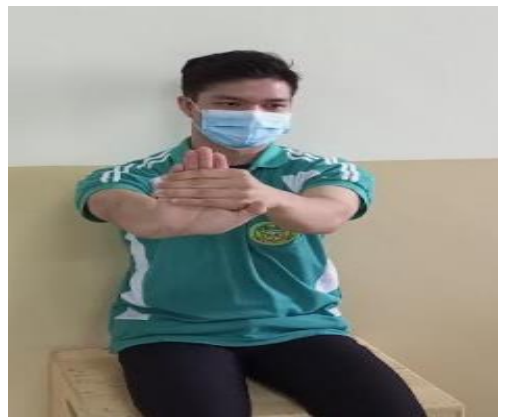

6) Peregangan Otot Extensor

a. Posisi awal duduk tegak, tangan lurus kedepan dengan pergelangan tangan menekuk ke bawah (flexi wrist)

b. Tangan yang lain menggenggam telapak tangan yang menekuk

c. Gunakan tangan yang menggenggam untuk menekuk (fleksi wrist) secara perlahan

d. Tahan posisi tersebut selama 30 detik

e. Lakukan bergantian pada kedua tangan (Lihat Gambar 6).

Gambar 6. Latihan Peregangan Otot Extensor

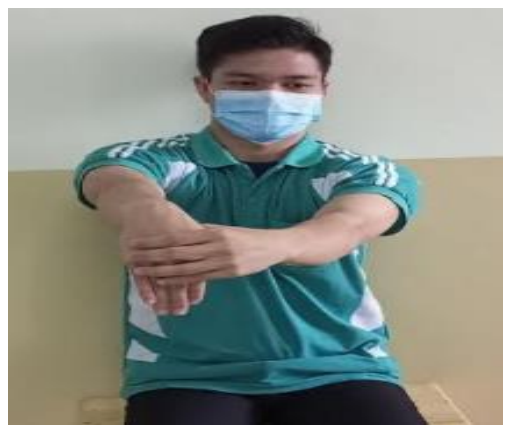

7) Menarik Pergelangan Tangan

a. Posisi awal duduk tegak tangan didepan dada dengan posisi telapak tangan menghadap ke bawah(pronasi)

b. Tangan yang lain menggenggam dari arah punggung tangan (dari atas)

c. Tangan yang digenggam dalam posisi diam/menahan, dan tangan yang lain melakukan tarikan secara perlahan sampai dirasakan peregangan pada pergelangan tangan

d. Tahan posisi tersebut selama 5 detik

e. Lakukan secara bergantian pada kedua tangan (lihat gambar 7).

Gambar 7. Latihan menarik pergelangan tangan

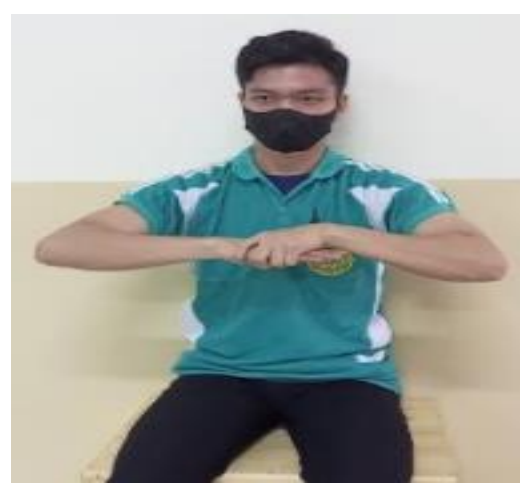




\section{HASIL DAN PEMBAHASAN}

Sebelum dilakukan sosialisasi, tim pelaksana melakukan pre test terlebih dahulu menggunakan angket yang berisi pertanyaan tentang tingkat pengetahuan peserta terkait pengertian, risiko, dan latihan yang lakukan untuk mencegah terjadinya CTS, begitu juga setelah kegiatan sosialisasi, tim kembali melakukan evaluasi tingkat pengetahuan peserta dengan post-test menggunakan angket yang sama. Hasil pre-test disajikan dalam grafik 1.

\section{Grafik 1. Distribusi tingkat pengetahuan peserta sebelum sosialisasi (pre-test)}

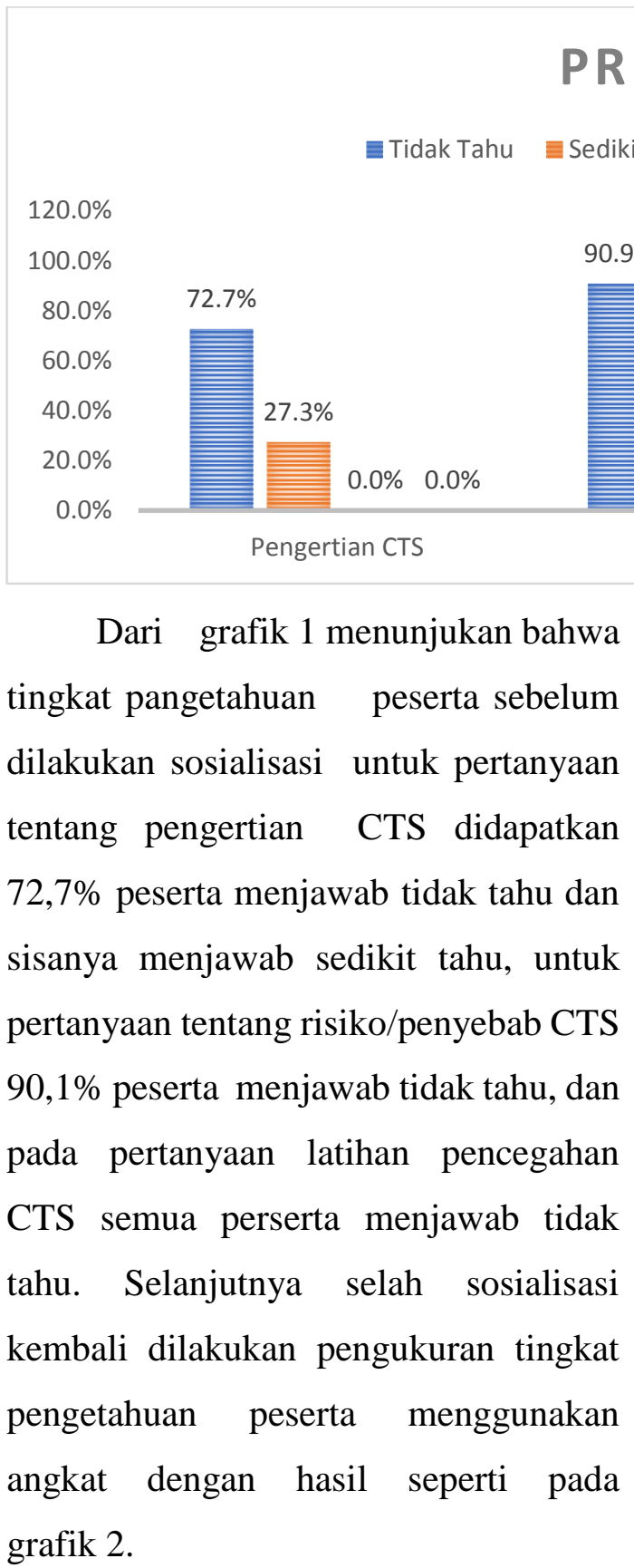

$9.1 \%$

$0.0 \% \quad 0.0 \%$ Risiko CTS
$100.0 \%$

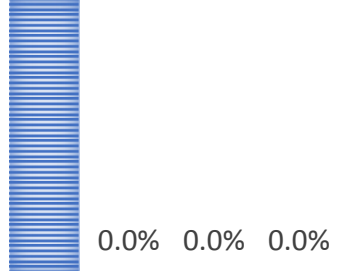

Latihan Pencegahan CTS
Dari grafik 1 menunjukan bahwa $72,7 \%$ peserta menjawab tidak tahu dan pertanyaan tentang risiko/penyebab CTS $90,1 \%$ peserta menjawab tidak tahu, dan pada pertanyaan latihan pencegahan CTS semua perserta menjawab tidak tahu. Selanjutnya selah sosialisasi kembali dilakukan pengukuran tingkat pengetahuan peserta menggunakan grafik 2
Pada grafik 2 dapat dilihat distribusi tingkat pengetahuan peserta menunjukan perbaikan dimana untuk pertanyaan mengenai pengertian CTS sebelum sosialisasi dominan peserta menjawab tidak tahu $(72,7 \%)$ tetapi setelah sosialisasi dominan peserta menjawab tahu $(72,7 \%)$ sisanya menjawab sangat tahu $(27,3 \%)$. Pada pertanyaan tentang risiko/penyebab CTS sebelum sosialisasi lebih dari $90 \%$ peserta menjawab tidak tahu, tetapi setelah sosialisasi berubah manjadi $77,3 \%$ peserta menjawab tahu, $18,2 \%$ peserta menjawab sangat tahu dan 
sisanya menjawab sedikit tahu. Untuk pertanyaan tentang latihan penceghan CTS sebelum sosialisasi seluruh peserta (100\%) menjawab tidak tahu, tetapi setelah sosialisasi didapatkan hasil $77,3 \%$ peserta menjawab tahu dan sisanya menjawab sangat tahu.

\section{Grafik 2. Distribusi tingkat pengetahuan peserta setelah sosialisasi (post-test)}

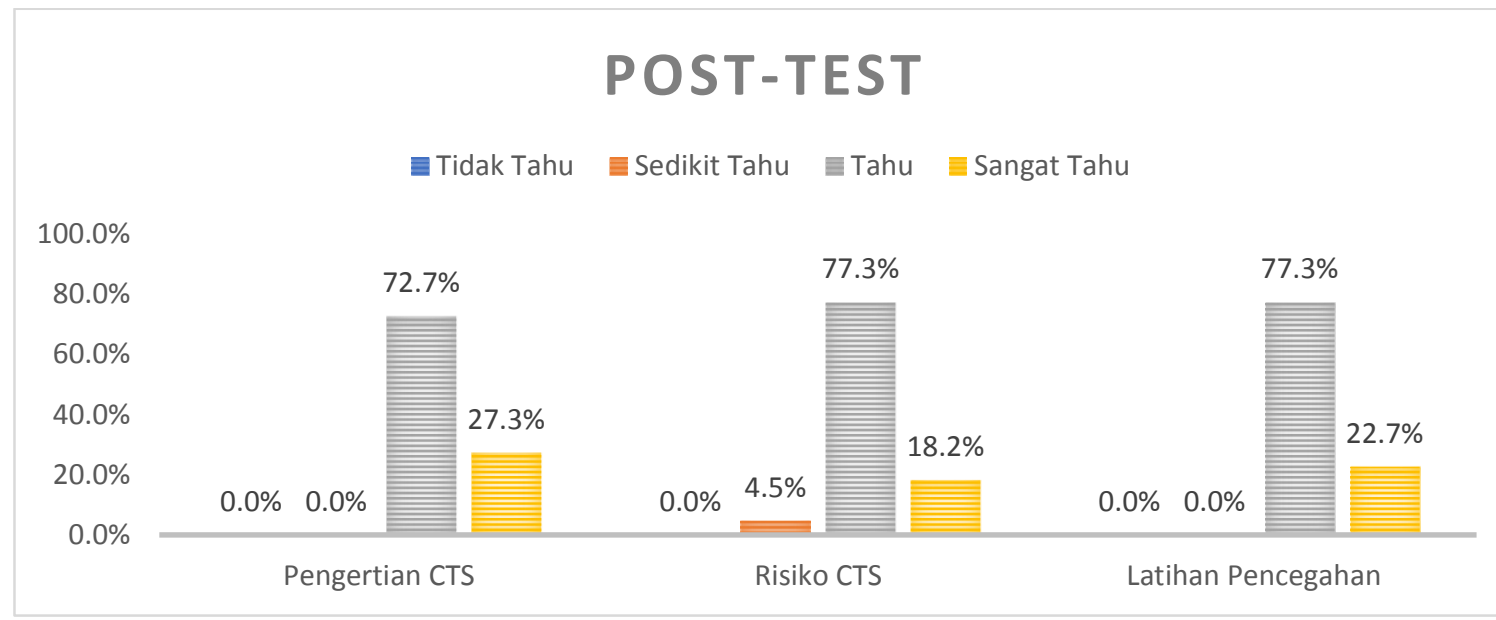

Hasil pre-test dan post-test menunjukan bahwa sosialisasi telah berhasil mencapai tujuan yang diharapkan, dimana terjadi peningkatan pengetahuan peserta terkait risiko, dan latihan pencegahan CTS. Selain itu, kriteria keberhasilan sosialisasi juga dapat dilihat dari antusiasme peserta selama mengikuti sosialisasi dengan banyaknya pertanyaan-pertanyaan saat sesi diskusi serta partisipasi aktif semua peserta untuk meperagakan gerakan latihan pencegahan CTS.

\section{KESIMPULAN}

Penggunaan gawai dalam waktu lama merupakan salah satu risiko penyebab dari CTS sehingga pemahaman tentang risiko dan cara pencegahannya sangat diperlukan. Sosialisasi telah berjalan dengan baik ditandai dengan peningkatakn pemahaman dan kemampuan peserta tentang risiko/penyebab CTS serta latihan yang dapat dilakukan untuk pencegahan CTS yang dapat dilihat dari perbedaan hasil pengukuran pre-test dan post-test peserta sosialisasi. Keberhasilan sosialisasi juga ditunjukan dengan antusiasme peserta selama mengikuti sosialisasi. 


\section{REFERENSI}

Alhazmi, A. A., Alzahrani, S. H., Baig, M., Salawati, E. M., \& Alkatheri, A. (2018). Prevalence and factors associated with smartphone addiction among medical students at King Abdulaziz University, Jeddah. Pakistan Journal of Medical Sciences, 34(4), 984-988. https://doi.org/10.12669/pjms.344.152 94

Baabdullah, A., Bokhary, D., Kabli, Y., Saggaf, O., Daiwali, M., \& Hamdi, A. (2020). The association between smartphone addiction and thumb/wrist pain: A cross-sectional study. Medicine, 99(10), e19124. https://doi.org/10.1097/MD.00000000 00019124

Batara, G. O., Doda, D. V. D., \& Wungouw, H. I. S. (2021). Keluhan Muskuloskeletal Akibat Penggunaan Gawai pada Mahasiswa Fakultas Kedokteran Universitas Sam Ratulangi Selama Pandemi COVID19. Jurnal Biomedik: Jbm, 13(2), 152-160.

https://doi.org/10.35790/jbm.13.2.202 1.31767

Koyama, T., Sato, S., Toriumi, M., Watanabe, T., Nimura, A., Okawa, A., Sugiura, Y., \& Fujita, K. (2021). A screening method using anomaly detection on a smartphone for patients with carpal tunnel syndrome:
Diagnostic case-control study. JMIR MHealth and UHealth, 9(3), 1-10. https://doi.org/10.2196/26320

Polat, Y. D., Aydın, E., Ince, F. S., \& Bilgen, M. (2020). Sonoelastic response of median nerve to rehabilitation in carpal tunnel syndrome. Journal of Ultrasonography, 20(81), e90-e94. https://doi.org/10.15557/JoU.2020.00 14

Pramandani, N. L. M. S., \& Wirawan, I. M. A. (2021). Faktor Risiko Carpal Tunnel Syndrome Pada Siswa Sekolah Menengah Atas Pemain Game Online Di Kota Denpasar. Archive of Community Health, 8(1), 91. https://doi.org/10.24843/ach.2021.v08 .i01.p07

Saito, K., \& Saito, Y. (2021). Relationship between Information and Communication Device Usage and Development of Hand Disorders. Inquiry (United States), 58, 1-6. https://doi.org/10.1177/00469580211 029607

Woo, E. H. C., White, P., \& Lai, C. W. K. (2016). Musculoskeletal impact of the use of various types of electronic devices on university students in Hong Kong: An evaluation by means of selfreported questionnaire. Manual Therapy, 26, 47-53. https://doi.org/10.1016/j.math.2016.0 7.004 